\title{
Dehydrated Broiler Litter: Agronomic Valorization by Application to Horticultural Crops
}

\author{
Francisco Antonio Cabaleriro ${ }^{1 *}$ Socorro Seoane-Labandeira² ${ }^{2}$ and Maria Elvira López-Mosquera ${ }^{1}$ \\ ${ }^{1}$ Institute of Agricultural Biodiversity and Rural Development (IBADER), University of Santiago de Compostela, Spain \\ ${ }^{2}$ Department of Soil Science and Agricultural Chemistry, University of Santiago de Compostela, Spain
}

Submission: December 22, 2017; Published: January 22, 2018

"Corresponding author: Francisco Antonio Cabaleiro, Institute of Agricultural Biodiversity and Rural Development (IBADER), University of Santiago de Compostela, Spain, Tel: +34 982 823134; Fax: +34 982 823001; Email: franciscoantonio.cabaleiro@gmail.com

Keywords: Poultry waste processing; Broiler litter; Organic fertilizers; Fertilizer value; Secondary salinization; Nitrate in lettuces

\section{Introduction}

One of the main concerns of modern society is the growing production and accumulation of waste, which poses major hazards to human health and environmental equilibrium. The European Union member countries produced more that 2.500 million tons of waste in 2014 [1]. Also, the European agricultural, forest and fishing sectors alone accounted for 197 million tons [2]. Breeding of broiler chickens (Gallus gallus domesticus) in Europe has increased in response to an increasing household consumption, with Spain as the fourth producer at present [3]. A total of 2.462.825.000 laying hens and broiler chickens were bred in 2016 [4]. If each 1000 birds are assumed to produce 0.71.4 tons of manure [5], then the overall production of litter in Europe last year was 1.6-3.4 million tons. The European Union's waste management policy aims at minimizing production and discharge while maximizing valorization. One way of valorizing poultry manure is by using it as organic fertilizer, thereby turning waste into a resource.

\section{Fresh Broiler Manure: Environmental and Health Problems}

Broiler litter consist largely of faeces, breeding material (e.g., sawdust, woodshavings, rice hulls, peanut hulls), feathers and feed remains. Its high contents in nutrients such as N, P and $\mathrm{K}$, and in organic matter, in addition to its low moisture, make it a highly valued product that is used mainly as a fertilizer for economically significant crops such as maize [6], cotton [7], soybean [8], forage [9] and horticultural plants [10]. Although poultry farms produce manure throughout the year, crops only need fertilization on a seasonal basis. As a result, manure often ends in waste stacks or is applied in excessive amounts or at wrong times, both of which raise environmental problems such as nitrogen emissions to the atmosphere, chemical and microbial contamination of aquifers, off-odours or spreading of bioactive pollutants such as antibiotics [11]. A number of studies conducted all over the world have shown that inappropriate management of fresh broiler manure poses environmental and health problems. Recent food safety crises such as those derived from the use of hormones for animal production, and contamination with dioxins or veterinary drug residues, has raised increasing concerns about food quality among consumers. The increasing social demand for stricter control and greater transparency in agricultural and animal breeding practices has led to major policy changes in the European Union in the form of stringent animal feeding control standards consistent with the guidelines set in the Food Safety white paper of 2000 [12].

\section{Processing Fresh Manure to Obtain Quality Organic Fertilizers}

A number of procedures such as composting [13], dehydration [14] and pyrolysis [15] have been developed over the last few decades to avoid the environmental and health problems caused by fresh manure. The resulting products can be certified for use as organic fertilizers with a low moisture content, metal contents meeting legal requirements, stabilized organic matter, hygienic conditions, and ease of transport and management. In addition to these economic advantages, procedures such as composting and dehydration have been found to degrade drug residues [16]. Few studies, however, have assessed the agronomic efficiency of processed manure against fresh manure.

Agronomic Valorization of a Commercial Dehydrated Broiler Litter Granulate

Several previous studies have investigated the benefits of drying broiler litter as regards handling and $\mathrm{N}$ contamination 
risks $[17,18]$. None, however, has examined the effects of drying and pelletizing on fertilizer value. Below are presented the main results obtained in greenhouse trials on horticultural crops to which pelletized dehydrated broiler litter (BL) obtained on a farm in northwestern Spain was applied for several years.

\section{Fertilizer value of pelletized dehydrated broiler litter}

Thermally treated broiler litter (BL) obtained over four production cycles was compared in terms of fertilizer value with fresh manure. Based on the results, dehydrated litter was more stable in composition than was the fresh product. Also, the former contained no faecal bacteria or antibiotic residues, and released no off-odours. In addition, pelletization facilitated transport, storage and application in the field [14].

\section{Effects of pelletized dehydrated broiler litter on horticultural crops}

Intensive greenhouse crops and organic crops require quality organic fertilizers, namely: fertilizers supplying the nutrients needed by the crop in a gradual manner, introducing no pathogens and raising the levels of no potential toxins such as metals or salts. This led us to set up greenhouse experiments involving various horticultural crops to assess the performance of $\mathrm{BL}$ as a fertilizer. Based on the results for four growth cycles of Trocadero lettuce (two under the more unfavourable weather conditions of autumn and summer and the other two under the more favourable conditions of spring and summer), a BL rate of 500-600gm-2, which supplied ca. $120 \mathrm{~kg}$ Nha-1, sufficed to increase production relative to conventional mineral fertilizer for greenhouse lettuce with figures similar to those for controlled release mineral fertilizers. Also, BL had a residual effect in both winter and summer that increased with increasing rate and allowed growing two consecutive lettuce crops with a single application [19].

Using $\mathrm{BL}$, at rates as low as $60 \mathrm{~kg} \mathrm{~N}$ ha-1, in pepper crop type 'Lamuyo' was observed similar production, quality (class I) and size (class G) than that obtained with a slow-release mineral fertilizer applied at $100 \mathrm{~kg} \mathrm{~N}$ ha-1 [19].

Although BL is effective for agricultural purposes, its high salt content can raise secondary salinization problems if used at high rates (especially in arid and semi-arid regions [20] $o$ in greenhouse soils). A field trial involving four cropping cycles revealed that applying BL to lettuce increased ECe in the soil in proportion to the rate used and to levels exceeding the acceptable salinity threshold for this crop (1.3dSm-1) with a rate of $1064 \mathrm{gm}-2$ (equivalent to $235 \mathrm{~kg}$ Nha-1). Although the organic fertilizer raised salt concentrations, this had no adverse impact on crop yield, so it was concluded that potential salinization in the long term could be avoided by using rates not exceeding $532 \mathrm{~g}$ $\mathrm{m}-2$ at any time of year when repeated applications were done [21].

One other caution is that broiler manure is especially rich in $\mathrm{N}$ and can thus raise the levels of this element in soil, thereby leading to excessive accumulation of nitrates in leafy crops such as lettuce. The nitrate concentration in these crops is a quality factor to be controlled for safety reasons [22]. This variable was examined by growing lettuce in a greenhouse at times of high and low irradiation for two years. The increase in lettuce nitrate levels caused by BL was not different from that resulting from the use of mineral fertilizers at similar equivalent rates $(120 \mathrm{~kg} \mathrm{~N}$ ha-1). In any case, the BL rate used under low irradiation should not exceed $1064 \mathrm{~g} \mathrm{~m}-2$ (235kg N ha-1) if nitrate concentrations in the outer leaves of lettuces are not to approach the maximum tolerated levels in European regulations [19].

\section{Conclusion}

Dehydrated broiler litter provides quality organic fertilizer that can compete with the usual mineral fertilizers for intensive horticultural crops; also, if applied at appropriate rates, it should cause no damage by effect of excess nutrients or salinity. In addition, BL improves the content in organic matter and biological activity of the soil. Therefore, it can be safely used on greenhouse crops or even in organic agriculture as it complies with its stringent restrictions.

\section{Acknowledgement}

This work was funded by the Directorate General for Research of Spain's Ministry of Science and Technology (Project AGL2000-04-81).

\section{References}

1. Eurostat (2017) Oficina europea de estadística.

2. Magrama (2017) El sector de la avicultura de carne en cifras.

3. (2016) Principales Indicadores Económicos 2016.

4. FAOSTAT (2017) Organización de las Naciones Unidas para la Alimentación y la Agricultura. Roma, Italy.

5. Patterson PH, Lorenz ES, Weaver WD (1998) Litter production and nutrients from commercial broiler chickens. J Appl Poult Res 7(3): 247-252.

6. Endale DM, Schomberg HH, Fisher DS, Jenkins MB, Sharpe RR, et al. (2008) No-till corn productivity in a Southeastern United States Ultisol amended with poultry litter. Agron J 100(5): 1401-1408.

7. Tewolde H, Sistani KR, Rowe DE, Adeli A, Johnson JR (2007) Lint yield and fiber quality of cotton fertilized with broiler litter. Agron J 99: 184194.

8. Adeli A, Tewolde H, Sistani K, Rowe D (2010) Comparison of broiler litter and commercial fertilizer at equivalent $\mathrm{N}$ rates on soil properties. Commun Soil Sci Plant Anal 41(20): 243-2447.

9. Sistani K, Adeli A, Tewolde H, Brink G (2008) Broiler chicken litter application timing effect on coastal Bermuda grass in southeastern U.S. Nutr Cycl Agroecosyst 81: 49-57.

10. Preusch PL, Adler PR, Sikora LJ, Tworkoski TJ (2002) Nitrogen and phosphorus availability in composted and uncomposted poultry litter. J Environ Qual 31(6): 2051-2057.

11. Schroeder PD, Radcliffe DE, Cabrera ML (2004) Rainfall timing and poultry litter application rate effects on phosphorus loss in surface runoff. J Environ Qual 33: 2201-2209.

12. Commission of European Communities (2000) White Paper on Food Safety. COM (1999) 719 final, p. 52. 
13. Guerra-Rodriguez E, Diaz-Ravina M, Vazquez M (2001) Co-composting of chestnut burr and leaf litter with solid poultry manure. Bioresour Technol 78(1): 107-109.

14. López-Mosquera ME, Cabaleiro F, Sainz MJ, López-Fabal A, Carral E (2008) Fertilizing value of broiler litter: Effects of drying and pelletizing. Bioresour Technol 99(13): 5626-5633.

15. Chan KY, Van Zwieten L, Meszaros I, Downie A, Joseph S (2207) Using poultry litter biochars as soil amendments. Aust J Soil Res 46(5): 437444.

16. Mohring SAI, Strzysch I, Fernandes MR, Kiffmeyer TK, Tuerk J, et al (2009) Degradation and elimination of various sulfonamides during anaerobic fermentation: A promising step on the way to sustainable pharmacy? Environ Sci Technol 43: 2569-2574.

17. Wood CW, Hall BM (1991) Impact of drying method on broiler litter analyses. Commun Soil Sci Plant Anal 22(15-16): 1677-1678.
18. Mondini C, Chiumenti R, da Borso F, Leita L, De Nobili M (1996) Changes during processing in the organic matter of composted and airdried poultry manure. Bioresour Technol 55: 243-249.

19. Cabaleiro Núñez FA (2013) Valorización agronómica del estiércol deshidratado y granulado de pollo en cultivos hortícolas. Universidad de Santiago de Compostela, Lugo, Spain, p. 205.

20. Adeli A, Twolde H, Sistani K, Rowe D (2010) Comparison of broiler litter and commercial fertilizer at equivalent $\mathrm{N}$ rates on soil properties. Commun Soil Sci Plant Anal. 41: 2432-2447.

21. Cabaleiro FA, Sainz MJ, Seoane-Labandeira S, López-Mosquera ME (2017) Salt effect of dehydrated broiler litter on organic lettuce. Biol Agric Horticb 1-13.

22. Reglamento (UE) no 1258/2011 de la Comisión de 2 de diciembre de 2011 que modifica el Reglamento (CE) no 1881/2006 por lo que respecta al contenido máximo de nitratos en los productos alimenticios. Diario Oficial de la Unión Europea L320 15-17.

This work is licensed under Creative Commons Attribution 4.0 License DOI:10.19080/ARTOAJ.2018.13.555885 